\title{
BEYOND THE EMERGENCY ROOM DOORS: REJECTING PATIENT ADMITTANCE AS SATISFACTION OF Hospital OBLIGATIONS UNDER EMTALA
}

Charlotte Fillenwarth ${ }^{*}$

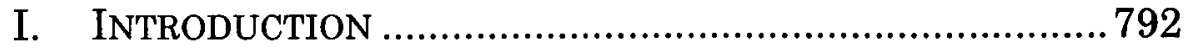

II. The History of Preventing Patient DumPing .........793 A. Historical Responses to Patient Dumping..............794

III. The EMERGENCY MEDICAL TREATMENT AND ACTIVE LABOR ACT (EMTALA) ............................................... 797

A. EMTALA's Medical Screening Requirement.........799

B. EMTALA's Stabilization Requirement ...................801

C. Enforcement of EMTALA......................................803

IV. EMERGENCE OF THE ISSUE: THE CIRCUIT SPLIT .............805

A. The Sixth Circuit Considers the Issue: Thornton v. Southwest Detroit Hospital...................................805

B. The Fourth Circuit Weighs In: Bryan v. Rectors and Visitors of University of Virginia ..........................807

C. The Supreme Court's Most Recent EMTALA Ruling: Roberts v. Galen of Virginia, Inc............................809

D. The Ninth Circuit Creates a New Standard:Bryant v. Adventist Health System/West ..........................810

E. The CMS Regulations Adopt the Ninth Circuit's Approach ......................................................... 811

F. The Sixth Circuit Responds: Moses v. Providence Hospital and Medical Centers, Inc. ........................814

V. DISCUSSION ....................................................................... 817

A. Rejecting the CMS Regulations .............................817

B. Plain Meaning...................................................... 819

C. Legislative Intent ................................................. 822

D. Policy Concerns...................................................... 824

1. The Sixth Circuit's Approach Does Not Supplant State Medical Malpractice Laws ......................824

* J.D. Candidate, 2014, Indiana University Robert H. McKinney School of Law, Indianapolis, Indiana; B.A., 2011, Purdue University, West Lafayette, Indiana. 
2. The Ninth Circuit's Approach Is Inconsistent with the Supreme Court's Holding in Roberts v.

Galen 827 VI. CONCLUSION 829

\section{INTRODUCTION}

Currently, Federal Circuit Courts are split over the proper interpretation of important obligations that the Emergency Medical Treatment and Active Labor Act (EMTALA) places on participating hospitals. Under EMTALA, hospitals must provide a medical screening to all patients who come to the hospital's emergency department. If a physician identifies an emergency medical condition, the hospital must provide the patient with stabilizing treatment prior to transfer or discharge. In the last decade, a common fact pattern has repeatedly emerged that EMTALA does not explicitly contemplate. This set of facts begins with a sick or injured individual coming to a hospital emergency room for treatment. After performing the proper medical screening, a physician discovers an emergency medical condition and admits the patient to the hospital for further treatment or testing. In most cases, the patient will spend between a few days and a few weeks at the hospital recovering before the hospital discharges the patient. Following the discharge, the patient's condition worsens or, in some cases, the patient dies. The patient or a representative files suit alleging that the patient's condition worsened because the hospital discharged the patient at a point when the individual was not medically stable. In these situations, courts are divided on the viability of patients bringing EMTALA claims in spite of hospital admittance.

The Fourth and Ninth Circuits represent the view that the stabilization requirement may be fulfilled by admitting a patient to the hospital. The Sixth Circuit represents the view that stabilization is only fulfilled when a patient's medical condition is not likely to deteriorate upon transfer 
or discharge. Under this view, a patient's admittance to an inpatient care unit is irrelevant in determining if the stabilization duty has been fulfilled. The Sixth Circuit's interpretation should be followed because it represents the plain meaning of the statute, honors the legislative intent, and provides consistency with the United States Supreme Court's holding in Roberts v. Galen of Virginia, Inc.

This Note begins by examining the history surrounding patient dumping and the early attempts to correct the widespread problem among the nation's hospitals. This will include a consideration of how common law doctrines, state legislation, and the Hill-Burton Act failed to rectify the problem. The second part of this Note will provide an overview of EMTALA's background and content. This will include a comprehensive examination of the stabilization provision and accompanying definitions. Next, this Note will describe the multiple interpretations of EMTALA's stabilization requirement articulated in Federal Circuit Court cases. Cases from the Sixth Circuit, Fourth Circuit, and Ninth Circuit will be introduced to illustrate the conflict among the various interpretations. The last part of this Note will present an analysis demonstrating the most appropriate approach to EMTALA's stabilization requirement. The Note concludes that the Sixth Circuit's interpretation is the proper approach to apply to patient treatment under EMTALA.

\section{The History of Preventing Patient Dumping}

Patient dumping is the "denial of or limitation in the provision of medical services to a patient for economic reasons and the referral of that patient elsewhere." 1 This practice occurs when an uninsured patient comes to a hospital emergency department seeking treatment. Once a hospital representative determines the patient is unable to pay for the required medical services, the hospital can either absorb the costs or "dump" the patient, either by referring the patient to another facility or simply turning

1 David A. Ansell \& Robert L. Schiff, Patient Dumping: Status, Implications, and Policy Recommendations, 257 JAMA 1500 (1987). 
the patient away. Because providing free medical services is an expensive and inefficient business model, the hospital is financially incentivized to dump the patient. This practice leads to serious societal harms for both patients and hospitals. ${ }^{2}$ Patients referred to alternative hospitals and clinics may experience poor medical outcomes, and city hospitals receiving these indigent patients bear a disproportionate share of the absorbed costs of providing free health care. ${ }^{3}$

\section{A. Historical Responses to Patient Dumping}

Under common law, it is well settled that hospital emergency departments are not obligated to accept patients for treatment. 4 Even so, some courts have carved out narrow exceptions based on the common law theories of reliance and abandonment. ${ }^{5}$ According to the reliance theory, "liability on the part of a hospital may be predicated on the refusal of service to a patient in the case of an unmistakable emergency, if the patient has relied upon a well-established custom of the hospital to render aid in such a case." 6 This requires proof that an unmistakable emergency existed, there was a well-established custom of providing care in such circumstances, and that the patient relied on that custom. ${ }^{7}$ This is a difficult standard to prove because the elements are vague and it requires proving the patient's mental state. The abandonment theory provides that a hospital may be held liable for the failure to treat a patient in the emergency department if it is found that the hospital began to render care and then abandoned the patient by discharge or transfer. ${ }^{8}$ Because it requires a

2 Id. at 1500-01.

3 Id.

4 See, e.g., Birmingham Baptist Hosp. v. Crews, 229 Ala. 398, 399

(1934); Brooks v. Md. Gen. Hosp., Inc., 996 F.2d 708, 710 (4th Cir. 1993).

5 See, e.g., Wilmington Gen. Hosp., v. Manlove, 54 Del. 15, 25 (1961); Stanturf v. Sipes, 447 S.W.2d 558, 561-62 (Mo. 1969).

6 Manlove, 54 Del. at 25.

7 Id. at $22-24$.

8 See, e.g., Le Juene Rd. Hosp., Inc. v. Watson, 171 So. 2d 202, 203 (Fla. Dist. Ct. App. 1965). 
finding that the hospital began to render care, this theory is limited to situations where a patient received some form of treatment before being transferred or turned away. These common law exceptions are narrow and provide only limited protection for uninsured patients in need of emergency services.

Another response to patient dumping is state-enacted legislation. States following this approach have addressed the issue of patient dumping by enacting legislation aimed specifically at providing emergency medical care to indigent patients. ${ }^{9}$ This response has proved to be largely inadequate. First, as there is no requirement to pass this type of protective legislation, only about half of all states have these statutes in place. ${ }^{10}$ Second, most of the enacted statutes have been unsuccessful due to unclear definitions of emergencies and limited enforcement. ${ }^{11}$

Enacted in 1946, Congress first attempted to address patient dumping at the federal level with the Hill-Burton Act. ${ }^{12}$ The statute provided federal funds for the construction and modernization of hospitals, the promotion of medical research, and the development of new facilities for medical treatment, diagnostics, and rehabilitation. ${ }^{13}$ In exchange for these funds, the statute required hospitals to first, be "made available to all persons residing in the territorial area of the applicant" and second, to provide "a reasonable volume of services to persons unable to pay." 14 An exception allowed hospitals to limit the provision of uncompensated services in accordance with financially feasibility. ${ }^{15}$ To satisfy the uncompensated services requirement, the Department of Health and Human Services (formerly the Department of Health, Education

9 Karen I. Treiger, Preventing Patient Dumping: Sharpening the Cobra's Fangs, 61 N.Y.U. L. REV. 1186, 1201 (1986).

10 Karen Rothenberg, Who Cares?: The Evolution of the Legal Duty to Provide Emergency Care, 26 Hous. L. REV. 21, 56 (1989).

11 Id. at 54.

12 Hospital Survey and Construction Act, 42 U.S.C. $\$ \S 291-291 \mathrm{~m}$ (West 2014).
$13 \quad I d . \S 291$.
$14 \quad I d . \S 291 \mathrm{c}(\mathrm{e})$.
$15 I d$. 
and Welfare) issued regulations specifying that the hospital must simply provide a reasonable amount of uncompensated services annually to indigent patients. 16 The regulations required hospitals to post notice of the availability of uncompensated services so that patients would be aware of such an option. ${ }^{17}$ To satisfy the community service requirement, the hospital could not deny emergency medical services to any person living in the hospital's service area "on the ground that the person is unable to pay for those services."18

The Hill-Burton Act proved unsuccessful because it failed to adequately provide emergency medical services for indigent patients. ${ }^{19}$ First, by 1986, just over half of all states participated in the Hill-Burton program to receive federal funds in exchange for an expansion of services to the indigent. ${ }^{20}$ Those states choosing not to participate were not bound by the statute's mandate. Second, the ambiguous language of the Hill-Burton Act failed to precisely define the two separate obligations that the statute imposed on participating hospitals. ${ }^{21}$ While the statute required hospitals to perform general community services as well as uncompensated services for indigent patients, most hospitals ignored the first requirement until the early 1970 s when a court ruled that the Hill-Burton Act mandated general community service. ${ }^{22}$ Next, neither the statute nor the regulations required states to maintain agencies to monitor hospital compliance, and the Department of Health

1642 C.F.R. $\S 124.503$ (2014).

17 Id. § 124.504 .

$18 \quad$ Id. $\$ 124.603(\mathrm{~b})(2)$.

19 See generally Michael A. Dowell, Hill-Burton: The Unfulfilled Promise, 12 J. HEALTH POL. POL'Y \& L. 153 (1987), available at http://jhppl.dukejournals.org/content/12/1/153.full.pdf.

20 Id. at 154.

21 See, e.g., Metro. Med. Ctr. \& Extended Care Facility v. Harris, 693 F.2d 775 (8th Cir. 1982) (considering the plain language of the statute, Congressional reports and hearings, and court decisions to determine the precise obligations that Hill-Burton conferred on participating hospitals).

22 See Cook v. Ochsner Found. Hosp., 61 F.R.D. 354, 361 (E.D. La. 1972) (finding that the Hill-Burton Act mandated community service obligations apart from the uncompensated services provided to indigent patients). 
and Human Services was ineffective in its enforcement of the Hill-Burton Act. ${ }^{23}$ Due to these deficiencies, the primary method of enforcing the required services to the community was individual complaints of noncompliance. ${ }^{24}$ Last, because the statute did not allow for punitive damages, hospitals had little incentive to treat the uninsured. ${ }^{25}$ When hospitals were found in violation of the statute, courts imposed fines and ordered hospitals to comply with the requirements of the Hill-Burton Act. ${ }^{26}$ For these reasons, Hill-Burton failed to remedy the problem of patient dumping in the United States.

\section{The EMERgency Medical Treatment and ACTIVE LABOR ACT (EMTALA)}

The problem of patient dumping continued to worsen as the costs of health care increased throughout the second half of the twentieth century. ${ }^{27}$ Cutbacks in government healthcare spending in the early 1980 s compounded the problem by crippling the Medicare and Medicaid programs. ${ }^{28}$ By the mid-1980s it was reported that, in the United States, an estimated 200,000 people were either refused medical treatment or transferred to another hospital each year due to the inability to pay. ${ }^{29}$ In a wellknown study conducted in Chicago, physicians analyzed 467 patients that had been transferred from other hospitals in

23 S. REP. No. 93-1285, at 7898 (1974); Dowell, supra note 19, at 162 (explaining that the enforcement mechanism "requires [the Department of Health and Human Services] to periodically investigate and ascertain the extent of facility compliance," and "to collect and review compliance data," but the "information provided in the reports is not detailed enough to document compliance adequately" and facilities fraudulently misrepresent data).

24 Dowell, supra note 19, at 162.

25 See generally Rothenberg, supra note 10, at 58.

26 Id. at 58-59.

27 Ansell \& Schiff, supra note 1, at 1500.

28 Id.

29131 CoNG. REC. E5520-02 (daily ed. Dec. 10, 1985) (statement of Rep. Fortney H. (Pete) Stark). 
the area to Cook County Hospital, a major public hospital. ${ }^{30}$ Of the transferred patients, eighty-nine percent were black or Hispanic and eighty-seven percent lacked insurance. ${ }^{31}$ Twenty-two percent of the patients that Cook County Hospital received required admittance to the intensive care unit, and twenty-four percent were in a clinically unstable condition upon arrival. ${ }^{32}$ The study concluded that hospitals transferred patients depending primarily on the patient's ability to pay, even when emergency medical conditions persisted. ${ }^{33}$ By 1985, because the Hill-Burton Act was proving to be ineffective and only twenty-two states had implemented local anti-dumping statutes, the nation was calling for a new federal initiative to address this growing problem. ${ }^{34}$

In 1986, Congress passed the Emergency Medical Treatment and Active Labor Act ${ }^{35}$ (EMTALA) as a part of the comprehensive Consolidated Omnibus Budget Reconciliation Act ${ }^{36}$ (COBRA) to offer an effective solution to the problem plaguing communities everywhere. The statute requires hospitals to provide medical screening examinations and stabilizing treatment to all individuals who come to a participating hospital's emergency department. ${ }^{37}$ Reflecting the legislature's concern for indigent patients, the statute specifically prohibits hospitals and physicians from delaying the required medical screening examination and any stabilizing treatment or transferring "in order to inquire about the individual's method of payment or insurance status." 38

30 Robert L. Schiff et al., Transfers to a Public Hospital. A Prospective Study of 467 Patients., 314 NEW ENG. J. MED. 552, 552-57 (1986).

$31 \quad$ Id. at 555.

32 Id. at $553-54$.

$33 \quad$ Id. at 556.

34 H.R. REP. No. 99-241, pt. 3, at 5 (1985), reprinted in 1986 U.S.C.C.A.N. 726, 727 .

$35 \quad 42$ U.S.C. $\$ 1395$ dd (2014).

36 Medicare and Medicaid Budget Reconciliation Amendments of 1985, Pub. L. No. 99-272, § 9121(b), 100 Stat. 164.

3742 U.S.C. $\$ 1395 \mathrm{dd}$.

$38 \quad$ Id. $\S 1395 \mathrm{dd}(\mathrm{h})$. 


\section{A. EMTALA's Medical Screening Requirement}

The responsibilities mandated by EMTALA apply to all hospitals that maintain an emergency department ${ }^{39}$ and maintain provider agreements with Medicare. ${ }^{40}$ Under EMTALA's medical screening requirement, the hospital must provide an appropriate medical screening examination, "within the capability of the hospital's emergency department", to any individual who comes to the emergency department in order to determine if an emergency medical condition exists. ${ }^{41}$ An individual has "come to the emergency department" if the individual presents himself or herself at the emergency department, arrives outside the emergency department on hospital property, or arrives at the emergency department by ambulance or helicopter. ${ }^{42}$ Some courts have also held that a patient being treated in an ambulance en route to the hospital has also "come to the emergency department" for the purposes of the statute. ${ }^{43}$ An "appropriate medical

$39 \quad I d . \S 1395 \mathrm{dd}(\mathrm{a})$ (specifying "[i]n the case of a hospital that has an emergency department...").

$40 \quad I d . \S 1395 \mathrm{dd}(\mathrm{e})(2)$.

$41 \quad$ Id. $§ 1395 \mathrm{dd}(\mathrm{a})$.

42 Special Responsibilities of Medicare Hospitals in Emergency Cases, 42 C.F.R. $\$ 489.24$ (b) (2014).

43 See Morales v. Sociedad Espanola de Auxilio Mutuo y Beneficencia, 524 F.3d 54 (1st Cir. 2008). The issue arose when an ambulance was called for an individual experiencing severe abdominal pain and vomiting in conjuncture with her recent nonviable ectopic pregnancy. Id. at 55 . Once loaded into the ambulance, the paramedic called a nearby hospital to notify the emergency department of the patient's condition and need for treatment. Id. A physician at the receiving hospital spoke to the paramedic and inquired as to whether the patient had medical insurance. Id. at 56. After learning the patient was uninsured, the physician promptly ended the call, and the paramedic understood this to mean that the hospital would not receive the patient. The patient was taken to a different hospital for treatment. $I d$.

In the case, the hospital argued it was not liable to the patient under EMTALA because the patient had not physically "come to the emergency department," but rather, the patient was in an ambulance en route to the emergency department. Id. at 56. The court rejected this line of reasoning as contrary to EMTALA's intent, and it found that a patient en route to the emergency department has "come to the emergency department" for the 
screening" requires the hospital to "apply uniform screening procedures to all individuals coming to the emergency room of the hospital requesting treatment." 44 Therefore, as long as a patient receives the same medical screening that any other patient would receive in the emergency department, a hospital will not be in violation of EMTALA for failure to diagnose. ${ }^{45}$ Courts universally agree that claims of this nature should be brought under state medical malpractice theories and not EMTALA. ${ }^{46}$

An "emergency medical condition" is defined in the statute as "a medical condition manifesting itself by acute symptoms of sufficient severity (including severe pain) such that the absence of immediate medical attention could reasonably be expected to result in..." placing the patient's health in "serious jeopardy," "serious impairment to bodily functions," or "serious dysfunction of any bodily organ or part." 47 In the case of a pregnant woman experiencing contractions, an "emergency medical condition" is present if "there is inadequate time to effect a safe transfer to another hospital before delivery" or transfer would threaten the health of the woman or her unborn child. ${ }^{48}$

purposes of the statute. Id. at 60. The court noted that under the hospital's interpretation, "an uninsured or financially strapped person could be bounced around like a ping-pong ball in search of a willing provider. That result would be antithetic to the core policy on which EMTALA is based." Id. at 61 .

44 In re Baby K, 16 F.3d 590, 595 (4th Cir. 1994) (explaining "[a] hospital fulfills this duty if it utilizes identical screening procedures for all patients complaining of the same condition or exhibiting the same symptoms."); see also Baber v. Hosp. Corp. of Am., 977 F.2d 872, 880 (4th Cir. 1992).

45 See, e.g., Jones v. Wake Cnty. Hosp. Sys., Inc., 786 F. Supp. 538, 544 (E.D.N.C. 1991) (stating that the medical screening requirement is "not designed to redress an incorrect diagnosis by a hospital; instead, it is merely an entitlement to receive the same treatment that is accorded to others similarly situated.").

46 See Baker v. Adventist Health, Inc., 260 F.3d 987, 993 (9th Cir. 2001); Battle v. Mem'l Hosp. at Gulfport, 228 F.3d 544, 557 (5th Cir. 2000); Baber, 977 F.2d at 880; Cleland v. Bronson Methodist Hosp., 917 F.2d 266, 270 (6th Cir. 1990).

$47 \quad 42$ U.S.C. $\S 1395 \mathrm{dd}(\mathrm{e})(1)(\mathrm{A})$ (2014).

$48 \quad$ Id. $\S 1395 \mathrm{dd}(\mathrm{e})(1)(\mathrm{B})$. 


\section{B. EMTALA's Stabilization Requirement}

Because the emergency medical screening requirement is treated as a threshold obligation, the stabilization requirement only attaches if an emergency medical condition is identified. 49 If a patient is found to have an emergency medical condition, the hospital must provide "such further medical examination and such treatment as may be required to stabilize the medical condition" 50 or "transfer of the individual to another medical facility." 51 Thus, the statute is structured such that, if the physician does not identify an emergency medical condition during the medical screening, the hospital has fulfilled its obligation under EMTALA and has no further duty to stabilize, so long as the medical screening was appropriate. ${ }^{52}$ This is true

49 See Eberhardt v. City of Los Angeles, 62 F.3d 1253, 1259 (9th Cir. 1995); Baber, 977 F.2d at 880; Gatewood v. Wash. Healthcare Corp., 933 F.2d 1037, 1041 (D.C. Cir. 1991); Cleland, 917 F.2d at 271.

$50 \quad 42$ U.S.C. $\S 1395 \mathrm{dd}(\mathrm{b})(1)(\mathrm{A})$.

$51 \quad$ Id. $\S 1395 \mathrm{dd}(\mathrm{b})(1)(\mathrm{B})$.

52 Eberhardt, $62 \mathrm{~F} .3 \mathrm{~d}$ at 1259 . The issue arose when a patient was presented in the emergency department with an unhealthy blood pressure, pulse, and respiration caused by snorting cocaine and then smoking a dangerously high dose of heroine. Id. at 1254. After administering Narcan to reduce the effects of the opioids, a physician performed a medical examination and found the patient's vitals to be within normal parameters. Id. The physician diagnosed the patient as having suffered a heroine overdose and discharged him with instructions to seek long-term methadone treatment at a nearby facility. Id. at 1255 . A day later, police found the patient breaking windows at a private residence and armed with a machete. The patient charged the police officers who returned gunfire, hitting the patient. A witness reportedly heard the patient shout "kill me" and "put me out of my misery." Id. The patient was pronounced dead at the hospital, and he was discovered to have only a small amount of alcohol in his system but no drugs of any kind. Id.

The patient's family brought a claim under EMTALA asserting that the hospital discharged the patient with an unstable mental condition when its physicians failed to detect his suicidal tendency. Id. The court disagreed finding that an appropriate medical screening examination had been performed according to EMTALA's requirements. Id. at 1257. The statute requires a screening "to identify acute and severe symptoms that alert the physician of the need for immediate medical attention to prevent serious bodily injury." Id. The statute does not require physicians to detect "conditions that are not manifested by acute and severe symptoms, nor 
even if an emergency medical condition did exist but was unidentified, because hospital physicians are held to an objective standard under EMTALA's emergency medical screening requirement. ${ }^{53}$ To the contrary, for a violation of the stabilization requirement to occur, a physician must have actual knowledge of the emergency medical condition and the hospital must have failed to stabilize or transfer the patient. 54 Requiring a physician to have "actual knowledge" of the emergency medical condition before a violation can occur reflects the overall purpose of the statute. The statute was enacted to ensure that hospitals do not refuse necessary medical care to indigent patients in emergency situations, not to create a national standard of medical care. ${ }^{55}$

The statute defines "to stabilize" as "to provide such medical treatment of the condition as may be necessary to assure, within reasonable medical probability that no material deterioration is likely to result from or occur during the transfer of the individual." 56 A hospital is deemed to have fulfilled this obligation if a patient refuses to consent to the necessary treatment for the medical condition. ${ }^{57}$ Likewise, if a patient refuses to consent to a beneficial transfer in accordance with the statute, the hospital is deemed to have fulfilled the stabilization requirement. ${ }^{58}$ When a patient refuses treatment or transfer ordinarily required by EMTALA, the hospital should take all reasonable steps to secure the patient's informed consent to the refusal in writing. ${ }^{59}$

those that do not require immediate medical attention to prevent serious bodily injury." Id. Here, the patient's acute symptoms were those resulting from a drug overdose. Id. Because those symptoms were treated and stabilized, the hospital fulfilled its EMTALA obligations, notwithstanding its failure to detect the patient's suicidal disposition. Id.

53 Id. at 1259.

54 See Vickers v. Nash Gen. Hosp., Inc., 78 F.3d 139, 140 (4th Cir. 1996); Urban v. King, 43 F.3d 523, 525.26 (10th Cir. 1994); Cleland, 917 F.2d at 268-69; Gatewood, 933 F.2d at 1041.

55 See Eberhardt, 62 F.3d at 1259.

$56 \quad 42$ U.S.C. $\S 1395 \mathrm{dd}(\mathrm{e})(3)(\mathrm{A})$.

$57 \quad$ Id. $\S 1395 \mathrm{dd}(\mathrm{b})(2)$.

$58 \quad$ Id. $\S 1395 \mathrm{dd}(\mathrm{b})(3)$.

$59 \quad$ Id. $\S 1395 \mathrm{dd}(\mathrm{b})$. 
A hospital must stabilize the patient prior to transfer to another hospital ${ }^{60}$ unless: (1) a patient, after acknowledging the risks of transfer, requests the transfer in writing; (2) the physician determines the benefits of immediate transfer will outweigh the risks and then signs a certification; or (3) the physician determines the benefits of immediate transfer will outweigh the risks and then a qualified medical person, in consultation with the physician, signs a certification. ${ }^{61}$ The hospital also need not stabilize a patient prior to transfer if the transfer qualifies as an "appropriate transfer."62 An appropriate transfer is one in which (1) the transferring hospital has minimized the risks of transfer by treating the patient within its capacity; (2) the receiving facility has the available resources for treatment and has agreed to accept the patient; (3) the transferring hospital has sent the receiving hospital the necessary medical records and other related documents; (4) the transfer is accomplished by qualified personnel; and (5) the procedure meets all other standards in the interest of the health and safety of the patient. ${ }^{63}$

\section{Enforcement of EMTALA}

Any individual who is harmed as a result of a hospital's violation of the statute may, "in a civil action against the participating hospital, obtain those damages available for personal injury under the law of the State in which the hospital is located." 64 Any hospital in violation of a provision of EMTALA is "subject to a civil money penalty of not more than $\$ 50,000$ [or not more than $\$ 25,000$ in the case of a hospital with less than 100 beds] for each such violation." 65 A physician who is responsible for the examination, treatment, or transfer of the patient and who negligently violates the statute by transferring a patient

$\begin{array}{ll}60 & I d . \S 1395 \mathrm{dd}(\mathrm{c})(1) \\ 61 & I d . \S 1395 \mathrm{dd}(\mathrm{c})(1)(\mathrm{A})(\mathrm{i})-(\mathrm{iii}) \\ 62 & I d . \S 1395 \mathrm{dd}(\mathrm{c})(1)(\mathrm{B}) \\ 63 & I d . \S 1395 \mathrm{dd}(\mathrm{c})(2)(\mathrm{A})-(\mathrm{E}) \\ 64 & \text { Id. } \S 1395 \mathrm{dd}(\mathrm{d})(2)(\mathrm{A}) . \\ 65 & I d .\end{array}$


where the physician knew the risks outweighed the benefits or misrepresents an individual's condition is "subject to a civil money penalty of not more than $\$ 50,000$ for each such violation." 66 An individual harmed by a direct violation of the statute or a hospital suffering financial loss resulting from a direct violation of the statute may initiate a civil action against the hospital at fault. 67

The key mechanisms for the enforcement of EMTALA are the monitoring efforts of the Department of Health and Human Services ("HHS") and claims made by private individuals. 68 HHS enforces EMTALA requirements through the Centers for Medicare \& Medicaid Services (CMS) ${ }^{69}$ and the Office of Inspector General (OIG). ${ }^{70}$ If a

$66 \quad I d . \S 1395 \mathrm{dd}(\mathrm{d})(1)(\mathrm{B})$.

$67 \quad$ Id. $\S 1395 \mathrm{dd}(\mathrm{d})(2)$. This section provides:

(2) Civil enforcement

(A) Personal harm

Any individual who suffers personal harm as a direct result of a participating hospital's violation of a requirement of this section may, in a civil action against the participating hospital, obtain those damages available for personal injury under the law of the State in which the hospital is located, and such equitable relief as is appropriate.

(B) Financial loss to other medical facility

Any medical facility that suffers a financial loss as a direct result of a participating hospital's violation of a requirement of this section may, in a civil action against the participating hospital, obtain those damages available for financial loss, under the law of the State in which the hospital is located, and such equitable relief as is appropriate.

Id.

68 Julia Ai, Does EMTALA Apply to Inpatients Located Anywhere in a Hospital?, 32 RUTGERS L.J. 549, 556 (2001) (citing Joan M. Steiber \& Linda J. Spar, EMTALA in the 90's Enforcement Challenges, 8 HEALTH MATRIX 57, 61 (1998)).

69 When EMTALA was enacted, prior to the creation of Medicare and Medicaid, the CMS was called the Health Care Financing Administration (HCFA). 
hospital is found to be in violation of EMTALA, the CMS may terminate the hospital's Medicare agreement ${ }^{71}$ and the OIG determines whether to impose civil penalties. ${ }^{72}$

\section{EMERGEnCE OF The IsSUe: The CirCuit SPlit}

When a patient arrives at a hospital's emergency department, the hospital must provide an appropriate medical screening. ${ }^{73}$ If a physician identifies an emergency medical condition, then the hospital is obligated to stabilize the patient or transfer the patient to another facility if necessary. ${ }^{74}$ In many cases, a patient with an emergency medical condition will be admitted to the hospital for further treatment and later discharged. While the statute mandates that patients in the emergency room with emergency medical conditions must be "stabilized" or "transferred," it does not specifically articulate how these obligations apply to patients who have been admitted to the hospital for further treatment and are no longer being cared for in the emergency department. More precisely, the statute does not expressly identify the point in time when hospitals have fulfilled their EMTALA obligations once a patient is admitted to the general hospital. This issue has been thoroughly considered since the enactment of EMTALA and three prominent and conflicting positions have been articulated by the Sixth Circuit, the Fourth Circuit, and the Ninth Circuit.

\section{A. The Sixth Circuit Considers the Issue: Thornton v. Southwest Detroit Hospital}

In 1990, the United States Court of Appeals for the Sixth Circuit addressed EMTALA's "stabilization" requirement in

$70 \mathrm{Ai}$, supra note 68, at 556 (citing Lauren A. Dame, The Emergency Medical Treatment and Active Labor Act: The Anomalous Right to Health Care, 8 HEALTH MatRIX 3, 11 (1998)).

$71 \quad 42$ C.F.R. $\S 489.24$ (g) (2013).

$72 \quad$ Id. $\$ 489.24(\mathrm{~h})(3)$.

$73 \quad 42$ U.S.C. $\S 1395 \mathrm{dd}(\mathrm{a})(2014)$.

$74 \quad$ Id. $§ 1395 \mathrm{dd}(\mathrm{b})$. 
Thornton v. Southwest Detroit Hospital. ${ }^{75}$ The court affirmed the lower court's ruling that the hospital had fulfilled its EMTALA obligations by stabilizing the patient once she had come to the emergency department. ${ }^{76}$ In the case, upon the patient's arrival to the emergency department, physicians discovered that the patient had suffered a stroke and admitted her to the hospital's intensive care unit. 77 The patient spent ten days in the intensive care unit and was treated for an additional eleven days in regular patient in-care. ${ }^{78}$ Because the patient could not afford to stay at the physician's preferred rehabilitation facility, the hospital discharged the patient to receive home care from her sister until another facility would accept her application. ${ }^{79}$ By the time the patient had gained admission to a new facility, two months had passed since her release from the hospital and her condition had seriously deteriorated. ${ }^{80}$ The patient brought a claim under EMTALA alleging that the hospital had failed to properly stabilize her condition prior to her discharge to home care. ${ }^{81}$ The district court granted the hospital's motion for summary judgment, and the patient appealed. 82

Although the hospital argued that EMTALA's stabilization requirement had been fulfilled once the patient had been admitted to the hospital's intensive care unit, the court found no basis for this contention. ${ }^{83}$ Instead, the court stated that a literal interpretation of the statute prohibits a hospital from discharging a patient who came to the emergency department before the condition has been medically stabilized without regard as to whether the patient was admitted. ${ }^{84}$ Emphasizing this point, the court stated that "emergency care does not always stop when a

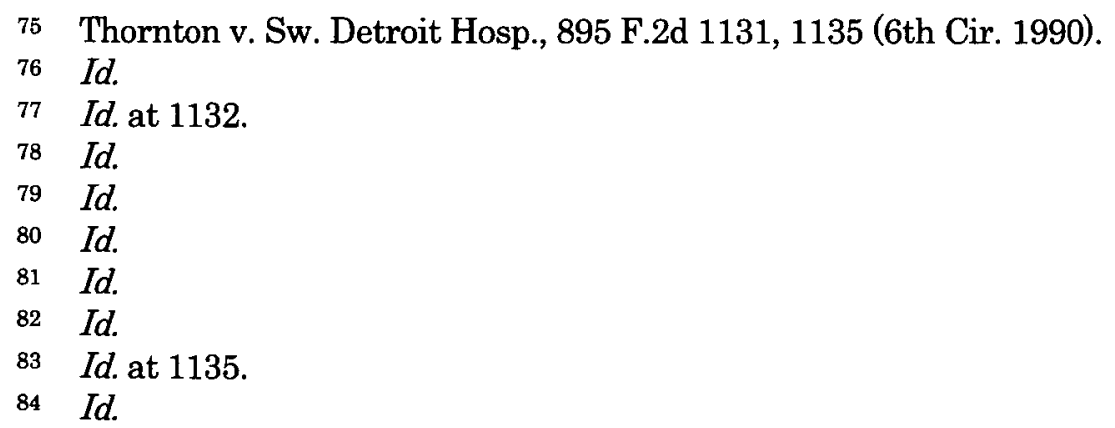


patient is wheeled from the emergency room into the main hospital." 85 This view reflects the common concern that permitting hospitals to fulfill the stabilization requirement through admission allows circumvention of EMATALA's mandate. ${ }^{86}$ Hospitals would have an incentive to develop policies to regularly admit patients with emergency medical conditions in order to simply fulfill EMTALA requirements and then discharge the patient without concern for liability. ${ }^{87}$ After identifying the proper interpretation of EMTALA's stabilization provision, the court applied the facts of the case and held that the patient had been medically stabilized prior to discharge. ${ }^{88}$ The court affirmed the district court's grant of summary judgment on the grounds that no genuine issue of material fact existed as to the patient's medically stabilized condition. ${ }^{89}$

\section{B. The Fourth Circuit Weighs In: Bryan v. Rectors and Visitors of University of Virginia}

When the United States Court of Appeals for the Fourth Circuit addressed EMTALA's stabilization requirement in 1996, it came to a different legal conclusion regarding the proper interpretation of the statute. In Bryan v. Rectors and Visitors of University of Virginia, the court held that a hospital had not violated EMTALA when an admitted patient died after physicians gave orders to not resuscitate the patient following twelve days of treatment. ${ }^{90}$ In this case, the patient was presented with an emergency medical condition in the emergency room and was admitted to the hospital. ${ }^{91}$ The physicians provided proper treatment but failed to ever medically stabilize the patient. Twelve days after the patient's admittance, physicians entered a "do not

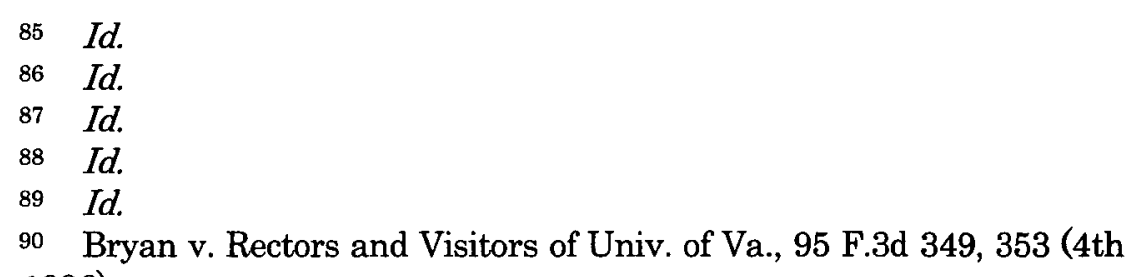
Cir. 1996).

91 Id. at 350. 
resuscitate order" against the family's wishes. ${ }^{92}$ During her next respiratory episode, the patient was not given stabilizing treatment and died as a result. ${ }^{93}$

The patient's family brought a claim asserting that EMTALA imposed an obligation on hospitals to treat patients for emergency medical conditions and, if needed, admit the patient and then continue to treat the patient's condition, no matter how long treatment was required to maintain a stabilized condition. ${ }^{94}$ The court flatly disagreed, and instead it stated that EMTALA's purpose was to ensure that hospitals provide stabilizing treatment to patients with emergency medical conditions. ${ }^{95}$ Once a patient was admitted, a physician's failure to treat would be regulated by state tort law. ${ }^{96}$ In coming to this conclusion, the court examined the statute's definition of "to stabilize," which means "to provide such medical treatment of the condition as may be necessary to assure, within reasonable medical probability, that no material deterioration of the condition is likely to result from or occur during the transfer of the individual." 97 The court interpreted this to mean that stabilization was only required in conjunction with an anticipated transfer and that the statute was "without any reference to the patient's long-term care within the system." 98 Therefore, the stabilization requirement was "intended to regulate the hospital's care of the patient only in the immediate aftermath of the act of admitting her for emergency treatment and while it considered whether it would undertake longer-term full treatment or instead

$\begin{array}{ll}92 & I d . \\ 93 & I d .\end{array}$

94 Brief of Appellant at 5, Bryan v. Rectors and Visitors of Univ. of Va., 95 F.3d 349 (4th Cir. 1996) (No. 95-2023) (contending "[i]f a hospital . . . accepts a patient with an emergency medical condition either by admission or transfer and continues stabilizing treatment for any period of time, whether it be one hour, one week or twelve days and then refuses such stabilizing treatment, such refusal of stabilizing treatment without transfer violates EMTALA.").

95 Id. at 351.

96 Id. at $351-52$.

97 Id. at 352.

$98 I d$. 
transfer the patient to a hospital that could and would undertake that treatment."99 The court emphasized that an individual may not bring an EMTALA claim if the patient was receiving stabilizing treatment and was never discharged or transferred, regardless of whether the patient was ever considered medically "stable." 100 Although the court clarified that an EMTALA violation could not occur if the patient had not been transferred, it also adopted the view that EMTALA's obligations are fulfilled once a patient is admitted.

\section{The Supreme Court's Most Recent EMTALA Ruling: Roberts v. Galen of Virginia, Inc.}

In 1999, the United States Supreme Court granted certiorari to decide an EMTALA issue in Roberts $v$. Galen of Virginia, Inc. ${ }^{101}$ Although the issue was relevant to the circuit split emerging in the Sixth and Fourth Circuits, Roberts addressed only the narrow issue of whether a claim alleging a violation of EMTALA's stabilization duty required the plaintiff to show that the violation was the result of the hospital's improper motive. ${ }^{102}$ The Supreme Court held that proving the hospital's improper motive was not required to succeed in a claim of this nature stating, "there is no question that the text of [the stabilization provision] does not require an 'appropriate' stabilization, nor can it reasonably be read to require an improper motive."103 Thus, when an individual brings an EMTALA claim asserting that a hospital failed to properly stabilize a patient, the individual need not prove that the failure resulted from a medical professional's improper motive. This releases patients from the difficult task of proving a subjective element such as intent. While the Court clarified some issues relating to the stabilization requirement, the

$99 \quad I d$.

$100 \quad$ Id. at 353.

101 Roberts v. Galen of Virginia, Inc., 111 F.3d 405 (6th Cir. 1997).

102 Roberts v. Galen of Virginia, Inc., 52 U.S. 249, 252 (1999).

103 Id. at 253. 
limited opinion failed to weigh in on the hospital's EMTALA obligation once a patient has been admitted.

\section{The Ninth Circuit Creates a New Standard: Bryant v. Adventist Health System/West}

In 2002, the United States Court of Appeals for the Ninth Circuit addressed the issue in Bryant v. Adventist Health System/West. ${ }^{104}$ The court affirmed the district court's holding that a hospital had fulfilled EMTALA's stabilization requirement by admitting the patient to the general hospital.105 The patient, a minor who was severely mentally disabled, came to the emergency room with pneumonia, an emergency medical condition. ${ }^{106}$ The patient was admitted to the hospital and although treated and recommended for discharge, a last-minute examination of the patient's chest $\mathrm{x}$-ray revealed a lung abscess. ${ }^{107}$ The physicians re-admitted the patient and transferred him to an intensive care unit at another hospital because there were no beds available at the original hospital. 108 The receiving hospital performed surgery and eventually discharged the patient approximately two weeks after transfer. ${ }^{109}$ Although he seemed to be improving, the patient died unexpectedly nine days later. ${ }^{110}$

Among other claims, the complaint alleged that the receiving hospital violated EMTALA's stabilization requirement by failing to stabilize the patient prior to discharge. ${ }^{111}$ To determine whether the hospital could be held liable, the court had to "decide when EMTALA's stabilization requirement ends." 112 The court first considered the Fourth Circuit's stance that the stabilization 2002).

104 Bryant v. Adventist Health Sys./West, Inc., 289 F.3d 1162 (9th Cir.

$$
\begin{array}{ll}
105 & I d . \\
106 & I d . \text { at } 1164 . \\
107 & I d . \\
108 & I d . \\
109 & I d . \\
110 & I d . \\
111 & I d . \text { at } 1163 . \\
112 & \text { Id. at } 1167 .
\end{array}
$$


requirement was not meant to apply to patients admitted to the hospital. ${ }^{113}$ Then the court considered the Sixth Circuit's stance that EMTALA's stabilization requirement is not limited to the emergency room and follows a patient until he or she has been stabilized or transferred, no matter how much time passes. ${ }^{114}$ Based on the statute's purpose of preventing patient dumping, the court determined that the hospital's obligation to stabilize ends when the patient is admitted. 115 The court expressed concern that if stabilization was required after the patient was admitted, there would be "anomalous result-patients" who, if treated in the emergency room first, would be protected by EMTALA even after admission, but patients who by-passed the emergency room would not be entitled to these protections. ${ }^{116}$

However, paying lip-service to the Sixth Circuit's concern that hospitals may admit patients to escape liability under EMTALA with no intent to properly stabilize, the court created an exception. ${ }^{117}$ The court provided that, although it would "not assume that hospitals use the admission process as a subterfuge to circumvent the stabilization requirement of EMTALA," if a patient could demonstrate that his or her particular admission was a ruse, then liability may attach. ${ }^{118}$ Therefore, if a patient wishes to bring an EMTALA claim asserting improper stabilization, and the patient was admitted to the hospital following an emergency department examination, then the patient must prove the admission was improperly motivated.

\section{E. The CMS Regulations Adopt the Ninth Circuit's Approach}

In 2003, the CMS promulgated regulations in an attempt to remedy the varied rulings on EMTALA's stabilization

$\begin{array}{ll}113 & I d . \\ 114 & I d . \text { at } 1167-68 . \\ 115 & I d . \text { at } 1168 . \\ 116 & I d . \text { at } 1169 . \\ 117 & I d . \\ 118 & I d .\end{array}$


requirement. The regulations reaffirmed the statute's language regarding stabilization, but they created an exception applicable to inpatients that addressed the circuit split. ${ }^{119}$ The regulation states:

If a hospital has screened an individual . . . and found the individual to have an emergency medical condition, and admits that individual as an inpatient in good faith in order to stabilize the emergency medical condition, the hospital has satisfied its special responsibilities under this section with respect to that individual. ${ }^{120}$

The regulation adopts the Ninth Circuit's position and, like the court in Bryant, provides an exception when patient admittance is determined to be a subterfuge by including the "good faith" language. In coming to this determination the authors commented, "[w]e believe that, as the agency charged with enforcement of EMTALA, it is appropriate to pay deference to the numerous Federal courts of appeal that have decided upon this issue."121

Although the final rule is unambiguous, the CMS struggled in reaching this conclusion. In fact, the originally proposed rule, published in the Federal Register in May of 2002, had adopted the exact opposite position. The proposed regulation stated, "admitting an individual whose emergency medical condition has not been stabilized does not relieve the hospital of further responsibility to the individual." 122 Instead, it required that "the individual's condition must be such that no material deterioration of the

11942 C.F.R. $\S 489.24(\mathrm{a})(1)(\mathrm{ii})$ (2013).

120 Id. $\S 489.24(\mathrm{~d})(2)(\mathrm{i})$.

121 Medicare Program; Clarifying Policies Related to the Responsibilities of Medicare-Participating Hospitals in Treating Individuals with Emergency Medical Conditions, 68 Fed. Reg. 53222-01, 53244 (proposed Sept. 9, 2003) [hereinafter Clarifying Policies] (making this conclusion following an exhaustive analysis of Bryant and its progeny.).

122 Medicare Program; Changes to the Hospital Inpatient Prospective Payment Systems and Fiscal Year 2003 Rates, 67 Fed. Reg. 31404-01, 31475 (proposed May 9, 2002). 
condition is likely, within reasonable medical probability, to result from or occur during a transfer." 123 The proposal cited a strict reading of the statute and the fear of systematic circumvention as the basis for coming to this conclusion. ${ }^{124}$ One commentator approvingly stated "this clarification will allow hospitals to find an endpoint to their EMTALA obligations, specifically when the patient's emergency [medical] condition is stabilized." 125 The CMS's later about-face was the result of extensive "comments" on the proposed rule and supposed deference to the Circuit Courts. ${ }^{126}$

As recently as February of 2012, the CMS has affirmed the 2003 regulations in a new set of proposed rules. ${ }^{127}$ The CMS stated "[w]e continue to believe that this policy is a reasonable interpretation of the EMTALA statute and is supported by several Federal courts that have held that an individual's EMTALA protections end upon admission as a hospital inpatient."128 This affirmation indicates the CMS's firm commitment to ending EMTALA's stabilization obligation when a patient is admitted to the hospital, and it signifies the improbability of a policy change in the near future.

$123 I d$

124 Id. (stating pointedly that "permitting inpatient admission to end EMTALA obligations would provide an obvious means of circumventing these requirements that would seemingly contradict the point of the statute to protect emergency patient health and safety. This point should be particularly evident in the case of a woman in labor, a central focus of the statute. Such women are frequently admitted, and the statute clearly contemplated protecting them until completion of the delivery (that is, stabilization). In addition, if an inpatient who had been admitted from the dedicated emergency department with an unstabilized emergency medical condition was never stabilized as an inpatient and is transferred, we would still apply EMTALA in reviewing the transfer. In this context, stability for transfer reflects a complex medical judgment that can be made only based on review of all relevant information in each particular case, including all conditions that could cause the patient to be medically unstable.").

125 Clarifying Policies, supra note 121, at 53244.

126 Id. at 53245.

127 Medicare Program; Emergency Medical Treatment and Labor Act (EMTALA): Applicability to Hospital Inpatients and Hospitals with Specialized Capabilities, 77 Fed. Reg. 5213-01 (proposed Feb. 2, 2012).

128 Id. at 5217. 
F. The Sixth Circuit Responds: Moses v. Providence Hospital and Medical Centers, Inc.

In 2009, the issue of EMTALA's stabilization requirement was once again in front of the United States Court of Appeals for the Sixth Circuit. In Moses v. Providence Hosp. and Medical Centers, Inc., the Sixth Circuit addressed the issue for the first time since the CMS released the 2003 regulations. ${ }^{29}$ Following its ruling in Bryant and disregarding the CMS regulations, the court reversed the district court's order granting summary judgment and held that admittance into an inpatient care unit at a hospital was not sufficient to fulfill the hospital's stabilization requirement under EMTALA. ${ }^{130}$

The chilling background of this case began on December 13th when the patient's wife brought her husband to the hospital's emergency department due to severe headaches, muscle soreness, high blood pressure, and vomiting. ${ }^{131}$ The patient also displayed signs of slurred speech, disorientation, hallucinations, and delusions and had reportedly "demonstrated threatening behavior" causing the wife to be "fearful of her safety." 132 The patient was admitted to the hospital for further testing. ${ }^{133}$ Over the next few days, the patient exhibited more concerning psychiatric symptoms and had allegedly told his wife he "had bought caskets."134 The physicians also learned that the patient had recently attempted to board a plane with a hunting knife. ${ }^{135}$ With this information and the results from other tests, the physicians ruled out an acute psychotic episode and planned to transfer the patient to the psychiatric unit for reassessment, "if the patient's insurance will accept" the charge. ${ }^{136}$ Although the transfer was

129 Moses v. Providence Hosp. and Med. Ctrs., Inc., 561 F.3d 573, 584 (6th Cir. 2009).

$\begin{array}{ll}130 & \text { Id. } \\ 131 & \text { Id. at } 576 . \\ 132 & \text { Id. } \\ 133 & \text { Id. } \\ 134 & \text { Id. } \\ 135 & \text { Id. } \\ 136 & \text { Id. }\end{array}$


arranged on December 17th because the patient was not "medically stable from a psychiatric standpoint," the patient was abruptly told he would be discharged on December 18th. ${ }^{137}$ In the discharge papers a physician stated that the patient was stable, and he was released on December 19th. ${ }^{138}$ On December 29th, ten days after his release, the patient murdered his wife. ${ }^{139}$

Among the many claims asserted, the decedent's representatives alleged that the hospital failed to stabilize the patient prior to his discharge, violating the stabilization requirement under EMTALA. ${ }^{140}$ The hospital filed a motion for summary judgment, claiming that, as a matter of law, it had fulfilled the stabilization requirement by admitting the patient to the hospital. ${ }^{141}$ The trial court granted the hospital's motion for summary judgment based on the patient's admittance. ${ }^{142}$ The trial court found that because the patient had received a proper medical screening and was subsequently admitted to the hospital, no genuine issues of material fact remained. 143 The patient's representatives appealed. ${ }^{144}$

The United States Court of Appeals for the Sixth Circuit reversed the lower court's holding with respect to the hospital. ${ }^{145}$ The court rejected the hospital's argument and held that "EMTALA imposes an obligation on a hospital beyond simply admitting a patient with an emergency medical condition to an inpatient care unit."146 The court began by reciting the relevant parts of the statute. When a patient is found to have an emergency medical condition, the hospital must provide "such treatment as may be required to stabilize the medical condition." 147 A patient is

$\begin{array}{ll}137 & I d . \\ 138 & I d . \text { at } 577 . \\ 139 & I d . \text { at } 576-77 . \\ 140 & I d . \text { at } 577 . \\ 141 & I d . \\ 142 & I d . \\ 143 & I d . \text { at } 578 . \\ 144 & I d . \\ 145 & I d . \text { at } 576 . \\ 146 & I d . \text { at } 582 . \\ 147 & I d .\end{array}$


stabilized when "no material deterioration of the condition is likely, within reasonable medical probability, to result from or occur during transfer." 148 "'Transfer' is defined in the statute to include moving the patient to an outside facility or discharging him." 149 Furthermore, EMTALA restricts transfer-which includes discharge-until the patient is stabilized. ${ }^{150}$ Therefore, the court found that "EMTALA requires a hospital to treat a patient with an emergency [medical] condition in such a way that, upon the patient's release, no further deterioration of the condition is likely." 151 Stated differently, fulfillment of EMTALA's stabilization requirement is based exclusively on the patient's medical condition.

The court next addressed the hospital's argument that the CMS regulation allowed patient admittance to fulfill EMTALA's stabilization requirement. The court began by noting that regulations promulgated by administrative agencies may be rejected if they are contrary to clear congressional intent.152 The court assessed congressional intent based on the language of the stabilization provision and the corresponding definitions and found that allowing admission to fulfill the stabilization requirement conflicted with the statute. ${ }^{153}$ Because the court found the CMS regulation to be contrary to the statute's plain language, the court rejected the regulation and did not afford it deference. ${ }^{154}$

$148 I d$

149 Id. at 579.

$150 \quad I d$.

151 Id. at 582.

152 Id. at 583 (quoting Gallagher v. Croghan Colonial Bank, 89 F.3d 275, 277-78 (6th Cir. 1996).

$153 \mathrm{Id}$.

154 Id. at 583-84. Following the deference analysis, the court brought attention to the fact that the events of the case occurred in December of 2002, months before the CMS regulations were published in 2003. Id. at 583. The court stated, "[e]ven if the CMS regulation could somehow be deemed consistent with the statute, its promulgation in 2003, after [the patient's] stay in the hospital ended, would preclude this Court from applying it to this case." Id. This is true because the regulation is silent on retroactivity, and retroactive application would unfairly attach legal consequences to events completed prior to its enactment. Id. at 584 . 


\section{DiscUSSION}

The Fourth Circuit represents the view that EMTALA's stabilization requirement is fulfilled when a patient is admitted to the hospital. ${ }^{155}$ The Ninth Circuit is aligned with the Fourth Circuit, but it provides an exception so that if a patient can prove he or she was admitted for the sole purpose of circumventing EMTALA's stabilization requirement, the hospital may still be held liable. ${ }^{156}$ Lastly, the Sixth Circuit represents the view that stabilization is only fulfilled when a patient's condition is not likely to deteriorate upon transfer or discharge. 157 Therefore, according to the Sixth Circuit, a patient's admittance to an inpatient care unit is irrelevant in determining if the hospital fulfilled its stabilization duty. ${ }^{158}$ The Sixth Circuit's interpretation should be followed because it represents the plain meaning of the statute, honors the legislative intent, and provides consistency with the United States Supreme Court's holding in Roberts v. Galen of Virginia, Inc.

\section{A. Rejecting the CMS Regulations}

The Sixth Circuit was permitted to hold contrarily to the 2003. CMS regulations because the language of EMTALA was not ambiguous and the regulation was adverse to legislative intent. The purpose of the release of the 2003 CMS regulations was to clarify the duty EMTALA conferred upon hospitals regarding stabilizing treatment provided to

Although the court mentions this issue-determinative fact, the court's primary analysis is not weakened because it does not rely on the lack of retroactivity to come to its ultimate conclusion regarding deference to the CMS regulation. Id.

155 See Bryan v. Rectors and Visitors of Univ. of Va., 95 F.3d 349, 352 (4th Cir. 1996).

156 See Bryant v. Adventist Health Sys./West, 289 F.3d 1162, 1169 (9th Cir. 2002)

157 See Moses, 561 F.3d at 579.

158 Id. 
patients in the emergency department. 159 By allowing hospital admittance to fulfill the statute's stabilization requirement, the CMS created a bright line rule for hospitals to follow and courts to enforce. Five years later, the Sixth Circuit held contrarily to the regulations, defying the CMS's newly established approach to EMTALA's stabilization requirement. 160 While the regulations specifically stipulated that EMTALA's stabilization requirement ends when a patient is admitted, the Sixth Circuit held that the CMS had improperly interpreted EMTALA and that admittance did not necessarily qualify as fulfillment of the stabilization requirement. ${ }^{161}$

When issues of statutory construction arise, courts must first inquire "whether Congress has directly spoken to the precise question at issue." 162 If Congress has articulated an exact position in the plain meaning of the statute, then the court "must give effect to the unambiguously expressed intent of Congress." 163 If the statute is silent on the issue or provides ambiguous language regarding the issue, then the court must look for guidance from any regulations promulgated by an agency charged with administering the statute. ${ }^{164}$ The court must then consider "whether the agency's answer is based on a permissible construction of the statute." 165 In making this determination, the court should give a degree of deference to the administrative agency. ${ }^{166}$ The court is bound to follow the agency's statutory interpretation as long as it constitutes a "permissible construction of the statute."167 It follows that

159 Clarifying Policies, supra note 121, at 53244 (explaining generally that " $[t]$ he final rule responds to public comments received on a May 9, 2002 proposed rule (67 FR 31404) that both reiterated the agency's interpretations under EMTALA and proposed clarifying changes relating to the implementation of the EMTALA provisions.").

160 See Moses, 561 F.3d at 573.

161 Id.

162 Chevron, U.S.A., Inc. v. Natural Res. Def. Council, Inc., 467 U.S. 837, 842 (1984).

163 Id. at 843.

164 Id.

165 Id.

166 Id. at $843-44$

167 Id. at 843. 
"[t]he judiciary is the final authority on issues of statutory construction and must reject administrative constructions which are contrary to clear congressional intent." 168 Congressional intent may be discerned by the plain meaning of the statutory language or, if the language is ambiguous, by the legislative history surrounding the enactment of the statute. ${ }^{169}$

In the case of EMTALA, the Sixth Circuit was permitted to determine whether Congress spoke directly to the stabilizing issue in the statute. If the court found direct language providing an exact position within EMTALA, then the court was required to give effect to the mandate of Congress. ${ }^{170}$ On the other hand, if the Sixth Circuit found the language relating to stabilization to be ambiguous or lacking, only then was the court permitted to consider any relevant regulations, in this case those published by the CMS. ${ }^{171}$ Before accepting CMS's regulations as binding, the Sixth Circuit had to decide whether the CMS regulations were based on a permissible construction of EMTALA, while giving proper deference to the CMS. Finally, the court was permitted to discard the CMS regulations if they appeared contrary to congressional intent as understood through the plain meaning of the statute and congressional records.

\section{B. Plain Meaning}

EMTALA's plain meaning, construed from the language of the statute, requires hospitals to stabilize patients prior to discharge or transfer, and it does not expressly limit hospital liability by ending the stabilization requirement once a patient is admitted. 172 The statute provides that

168 Id. at 843 n.9.

169 See id. at $842-43$ (providing a general framework for determining legislative intent by first examining the statutory language and then various congressional records).

170 See id.

171 See id.

17242 U.S.C. $§ 1395 \mathrm{dd}(\mathrm{b})(1)$ (2014). The statute provides:

(1) In general 
when a patient is found to have an emergency medical condition, the hospital must provide "such further medical examination and such treatment as may be required to stabilize the medical condition" or "transfer of the individual to another medical facility."173 The statute thus contemplates "stabilization" in terms of medical treatment but not administrative procedures such as admittance.

According to the statute, the definition of "to stabilize" is "to provide such medical treatment of the condition as may be necessary to assure, within reasonable medical probability, that no material deterioration of the condition is likely to result from or occur during the transfer of the individual from a facility." 174 Transfer means "the movement [including the discharge] of an individual outside a hospital's facilities at the direction of any person employed by... the hospital."175 Therefore, a patient must be provided with enough medical treatment as may be necessary to reasonably assure the medical condition will not deteriorate once a patient is transferred to another hospital or discharged. This makes clear that the obligation EMTALA imposes may only be fulfilled when a patient has received the appropriate medical care. ${ }^{176}$ Because the statute makes no reference to limiting this care to patients in the emergency room, a patient's admittance into an inpatient

If any individual (whether or not eligible for benefits under this subchapter) comes to a hospital and the hospital determines that the individual has an emergency medical condition, the hospital must provide either--

(A) within the staff and facilities available at the hospital, for such further medical examination and such treatment as may be required to stabilize the medical condition, or

(B) for transfer of the individual to another medical facility in accordance with subsection (c) of this section.

Id. $\S 1395 \mathrm{dd}(\mathrm{b})$.

Id. $\S 1395 \mathrm{dd}(\mathrm{e})(3)(\mathrm{A})$. 1990). 
care unit is irrelevant in determining whether EMTALA's stabilization requirement has been fulfilled. ${ }^{177}$

Furthermore, a comparison of the medical screening requirement found in section (a) and the stabilization requirement found in section (b) suggests that the statute contemplates patients being admitted to the hospital in order to satisfy the required stabilizing treatment. ${ }^{178}$ The statute requires patients who come to the "hospital emergency department" to be screened to determine whether an emergency medical condition exists. ${ }^{179}$ Once an emergency medical condition has been identified, the "hospital" must provide the necessary stabilizing treatment to the patient. 180 While the screening requirement is assigned to the hospital emergency department, the stabilization requirement is assigned simply to the hospital. ${ }^{181}$ This change in wording indicates a change in meaning within the statute, particularly that stabilizing treatment in accordance with the provision must be provided, regardless of whether the patient is admitted to the general hospital. ${ }^{182}$ Because the CMS regulation is in direct conflict with the statute's plain meaning, the Sixth

177 This reasoning is consistent with court decisions finding that EMTALA applies not just to patients who are indigent, uninsured or otherwise unable to pay, but to all patients who come to the emergency department. In those cases, the courts found that clear language and a lack of provisions stating otherwise indicated that EMTALA applied to all patients in the emergency department. See, e.g., Cleland v. Bronson Methodist Hosp., 917 F.2d 266, 269 (6th Cir. 1990); Power v. Arlington Hosp. Ass'n, 42 F.3d 851, 857 (4th Cir. 1994); Summers v. Baptist Med. Ctr. Arkadelphia, 91 F.3d 1132, 1137 (8th Cir. 1996). The court in Cleland stated that although, "nothing in the legislative history show[ed] that Congress had any concern about the treatment accorded any patients other than the indigent ... Congress wrote a statute that plainly has no such limitation." Cleland, 917 F. 2d at 269.

178 See Thornton, 895 F.2d at 1134.

17942 U.S.C. $\$ 1395 \mathrm{dd}(\mathrm{a})$.

$180 \quad$ Id. $\$ 1395 \mathrm{dd}(\mathrm{b})(1)$.

181 Id. $\S 1395 \mathrm{dd}(\mathrm{a})-(\mathrm{b})$.

182 Thornton, 895 F.2d at 1134 (concluding "[t]he reasonable inference from this change in wording is that once a patient is found to suffer from an emergency medical condition in the emergency room, she cannot be discharged until the condition is stabilized, regardless of whether that patient stays in the emergency room."). 
Circuit is not required to give deference to the administrative agency's statutory construction.

\section{Legislative Intent}

Even if the statute is assumed to be ambiguous, the legislative intent behind EMTALA supports the Sixth Circuit's holding in Moses. As articulated in Congressional Reports, EMTALA was enacted to address the "the provision of adequate emergency room medical services to individuals who seek care."183 Particularly, Congress was concerned with hospitals' failure to provide treatment to patients coming to the emergency department, which resulted in medically inappropriate transfers or discharges. ${ }^{184}$ The renewed interest in indigent care was the result of numerous reports indicating that patients without insurance were simply not treated or transferred to another facility regardless of the patient's condition and without notifying the receiving hospital. 185 Congress addressed the reports stating:

There is some belief that this situation has worsened since the prospective payment system for hospitals became effective. The Committee wants to provide a strong assurance that pressures for greater hospital efficiency are not to be construed as license to ignore traditional community responsibilities and loosen historic standards. [Under the statute] [a]ll participating hospitals with emergency departments would be required to provide an appropriate medical screening examination for any individual who requests it

${ }_{183}$ H. R. REP. NO. 99-241, pt. 3, at 5 (1985), reprinted in 1986 U.S.C.C.A.N. 726, 727.

184 Id. at 743 (articulating that "[s]tabilization includes adequate evaluation and initiation of treatment to assure the transfer of a patient will not, within reasonable medical probility [sic], result in death, or loss or serious impairment of bodily parts or organs.").

185 H. R. REP. No. 99-241, pt. 1, at 27 (1985), reprinted in 1986 U.S.C.C.A.N. 579, 605. 


\begin{abstract}
. . to determine whether an emergency medical condition exists or if the patient is in active labor. ${ }^{186}$
\end{abstract}

The legislature summarized its position stating it was "most concerned that medically unstable patients [were] not being treated appropriately."187

Some courts have asserted that EMTALA was enacted to "prevent a distinct and rather narrow problem of patient dumping, or the practice of refusing to admit or summarily transferring a patient based on a perceived inability to pay for hospital services."188 This line of cases stands for the proposal that EMTALA's primary purpose was to prohibit hospitals from refusing to initiate medical care in the emergency room for uninsured patients. ${ }^{189}$ These cases contend that EMTALA does not exist to regulate the actual treatment patients receive, but rather, it exists to ensure that hospitals do not turn patients away. ${ }^{190}$ Although EMTALA does address patient dumping, based on the legislative history, Congress was concerned with more than compelling hospitals to receive indigent patients into the emergency room. In fact, the statute does not mention indigent patients, and courts have held that EMTALA

186 Id.

187 Id. (providing "[t]he Committee wants to provide a strong assurance that pressures for greater hospital efficiency are not to be construed as license to ignore traditional community responsibilities and loosen historic standards.")

188 James v. Jefferson Reg'l, No. 4:12CV267 JAR, 2012 WL 1684570, *3 (E.D. Mo. May 15, 2012); See also Bryan v. Rectors and Visitors of Univ. of Va., 95 F.3d 349, 352 (4th Cir. 1996); Summers v. Baptist Med. Ctr. Arkadelphia, 91 F.3d 1132, 1132 (8th Cir. 1996); Hunt v. Lincoln Mem'1 Hosp., 317 F.3d 891, 894 (8th Cir. 2003); Vickers v. Nash Gen. Hosp., Inc., 78 F.3d 139, 142 (4th Cir. 1996).

189 Bryan, 95 F.3d at 352 (concluding "EMTALA seeks to achieve the limited purpose of its enactment by requiring that the hospital provide limited stabilizing treatment to or an appropriate transfer of any patient that arrives at with an emergency condition.").

190 See Jefferson Reg'1, 2012 WL 1684570, at *3; see also Danielle Sapega, Federal Code Blue: The Emergency Medical Treatment and Active Labor Act's Prolonged Venture into Malpractice Law, 29 TEMP. J. ScI. TECH. \& ENVTL. L. 99 (Spring 2010). 
applies to all individuals who come to the emergency department. ${ }^{191}$ The legislature was equally concerned with ensuring that hospitals did not turn indigent patients away as it was concerned with providing adequate treatment once a patient was accepted into the emergency department. 192

\section{Policy Concerns}

In addition to examining legislative intent based on the plain meaning of the statute and the congressional record, it is also important to consider the policy implications of EMTALA's provisions. Of concern are the statute's interaction with state medical malpractice legislation and the interplay between the proper interpretation of the stabilization requirement and the Supreme Court's holding in Roberts $v$. Galen of Virginia Inc. Under the Sixth Circuit's interpretation, state medical malpractice legislation is left undisturbed and the stabilization requirement is consistent with Supreme Court precedent.

\section{The Sixth Circuit's Approach Does Not Supplant State Medical Malpractice Laws}

Courts have universally held that EMTALA was not enacted as a federal medical malpractice statute and that it does not provide a federal standard of care. ${ }^{193}$ Therefore,

191 See Cleland v. Bronson Methodist Hosp., 917 F.2d 266, 269 (6th Cir. 1990) (stating that although some argue EMTALA should only apply to the indigent, "Congress wrote a statute that plainly has no such limitation on its coverage."); Power v. Arlington Hosp. Ass'n, 42 F.3d 851, 857 (4th Cir. 1994) (noting "[t]he language of subsection 1395dd(a) simply refers to 'any individual' who presents to the emergency room."); Roberts v. Galen of Va., Inc., 525 U.S. 249, 252 (1999) (finding that proof of an improper motive, such as the patient's inability to pay for medical services, was not required for a failure to stabilize claim under EMTALA.)

192 H.R. REP. No. 99-241, pt. 3, at 5 (1985), reprinted in 1986 U.S.C.C.A.N. 726, 727 (describing the general medical obligations that hospitals must fulfill when treating a patient who comes to the emergency department).

193 See Holcomb v. Monahan, 30 F.3d 116, 117 (11th Cir. 1994) (stating "[s]ection $13995 \mathrm{dd}(\mathrm{a})$ is not designed to redress a negligent diagnosis by the 
EMTALA should not be considered a substitute for state law medical malpractice claims. ${ }^{194}$ This universal understanding of the statute leads some commentators to assert that an extension of EMTALA coverage to hospital inpatients would allow the federal statute to supersede state medical malpractice laws already in place. ${ }^{195}$ Indeed, in considering extending EMTALA protection to inpatients, the court in Morgan v. N. MS Med. Ctr., Inc. remarked:

This approach also seems vulnerable to abuse, inasmuch as it would allow for an open-ended, uncabined duration of the stabilization requirement with no logical limiting principle. Under this line of reasoning, then, the stabilization duty could be imputed as extending indefinitely after a patient's admission and potentially poaching on regulatory territory patrolled by state malpractice law, an outcome which runs directly counter to the stated purpose of EMTALA. ${ }^{196}$

Other courts have shared this concern and have ruled against allowing EMTALA to protect hospital inpatients. ${ }^{197}$

Although a valid concern, this argument conflates the Sixth Circuit's approach to stabilization. The Sixth Circuit held that "a hospital may not release a patient with an emergency medical condition without first determining that the patient has actually stabilized, even if the hospital

hospital; no federal malpractice claims are created."); Summers, 91 F.3d at 1132.

194 See Bryan, 95 F.3d at 352; Power, 42 F.3d at 857.

195 See Bryant v. Adventist Health Sys./West, Inc., 289 F.3d 1162, 1168-69 (9th Cir. 2002) (commenting that Congress enacted EMTALA to create a new cause of action not found in state tort law that seeks to remedy the failure to treat patients but not to duplicate preexisting protections.).

196 Morgan v. N. MS Med. Ctr., Inc., 403 F. Supp. 2d 1115, 1129 (S.D. Ala. 2005) affd sub nom. Morgan v. N. Mississippi Med. Ctr., Inc., 225 F. App'x 828 (11th Cir. 2007).

197 See Bryant, 289 F.3d at 1169. 
properly admitted the patient." 198 Therefore, the Sixth Circuit's application of EMTALA to inpatients is contingent on the patient's transfer to another facility or discharge. EMTALA would not apply in a situation where the hospital was continuously treating an admitted patient but failed to achieve stabilization before the patient's death. This is consistent with the language of EMTALA which defines "stabilized" as meaning "no material deterioration of the condition is likely, within reasonable medical probability, to result from or occur during the transfer of the individual from a facility."199 Additionally, this approach embraces a policy that requires a hospital to properly treat a patient who comes to the emergency department before releasing the patient in order to prevent the widespread problem of patient dumping.

The Sixth Circuit's approach has been misconstrued to apply to all cases where a patient has come to the emergency room and then been admitted to the hospital. ${ }^{200}$ However, for inpatients to assert a valid EMTALA claim based on stabilization, the alleged violation must have occurred in conjuncture with transfer or discharge. 201 Otherwise, the standard of care that binds medical professionals regulates claims of negligent treatment for

198 Moses v. Providence Hosp. and Med. Ctrs., Inc., 561 F.3d 573, 583 (6th Cir. 2009) (emphasis added).

19942 U.S.C. $\S 1395$ dd(e)(3)(B) (2014) (emphasis added).

200 For example, in the Appellee's Brief in Bryant, the hospital argued that EMTALA did not apply to inpatients because state malpractice laws regulated medical and ethical treatment in those situations. Brief of Defendant-Appellee at 22-23, Bryant v. Adventist Health Sys./West, Inc. 289 F.3d 1162 (9th Cir. 2002) (No. 00-16399). In support of its position, the Appellee cited to Hussain v. Kaiser Found. Health Plan of Mid-Atl. States, Inc., a case in which a patient was brought to the emergency room, admitted to the hospital, and died the next day while being treated in the hospital. Hussain v. Kaiser Found. Health Plan of Mid-Atl. States, Inc., 914 F. Supp. 1331, 1332 (E.D. Va. 1996). However, the patient in Hussain was not "transferred" within the meaning of EMTALA, so the stabilization requirement was not triggered and the only possible claim the patient could assert was medical malpractice. Thus, the Appellee's reliance on that case for the proposition that EMTALA's applications to inpatients would duplicate malpractice was ill-founded.

201 See 42 U.S.C. $\$ 1395 \mathrm{dd}(\mathrm{b})(1)(\mathrm{A})$. 
inpatients. Although this distinction does not completely avoid a invasion of state medical malpractice law, it significantly reduces the overlap and distinguishes actions that give rise to EMTALA claims and actions that give rise to state medical malpractice claims.

\section{The Ninth Circuit's Approach Is Inconsistent with the Supreme Court's Holding in Roberts v. Galen}

The Ninth Circuit's exception to ending EMTALA's stabilization requirement once a patient is admitted is inconsistent with the Supreme Court's holding in Roberts $v$. Galen of Virginia Inc. Although the Ninth Circuit's ruling was in favor of allowing admittance to end the stabilization requirement, the court recognized the policy concerns highlighted in the Sixth Circuit's decision. The Ninth Circuit itself stated, "[w]e agree with the Sixth Circuit that a hospital cannot escape liability under EMTALA by ostensibly. 'admitting' a patient, with no intention of treating the patient, and then discharging or transferring the patient without having met the stabilization requirement." 202 Instead of following the Sixth Circuit however, the court simply created an exception allowing inpatients to hold hospitals liable under EMTALA if they could demonstrate their admission was a "ruse to avoid EMTALA's requirements." 203 This places the burden on inpatients to prove that a physician acted with subjective intent to circumvent EMTALA by admitting the patient.

Not only is this an incredibly difficult standard to meet, it is also inconsistent with the Supreme Court's holding in Roberts. Although the Roberts decision did not determine when EMTALA's stabilization requirement ended, it did decide a related issue. The Court reversed the Court of Appeal's decision that held "in order to recover in a suit alleging a violation of [EMTALA's stabilization requirement], a plaintiff must prove that the hospital acted

202 Bryant, 289 F.3d at 1169.

203 Id. 
with an improper motive in failing to stabilize."204 Under the Court of Appeals ruling, even if a patient could objectively prove the hospital failed to meet the stabilization requirement by discharging or transferring the patient before the patient was medically stable, the patient would still be required to show the failure was the result of an improper motive. The Supreme Court rejected this ruling stating that the statute clearly did not require this showing of improper motive either expressly or implicitly. ${ }^{205}$

The Ninth Circuit requires this improper motive showing for a claim asserting a violation of EMTALA's stabilization requirement any time a patient has been admitted to the hospital. ${ }^{206}$ Because the Roberts opinion rejected this evidentiary requisite to prove any violation of the stabilization requirement, it would likely reject the same requisite when asserting a stabilization violation after a patient has been admitted. The Supreme Court would hold that the statute cannot be reasonably read to require such proof of an improper motive to satisfy the Ninth Circuit's exception. Because the Supreme Court would not accept the Ninth Circuit's exception, the Ninth Circuit's position would be exactly aligned with the Fourth Circuit, that is, the stabilization requirement is fulfilled when a patient is admitted to the hospital, without exception. As the Ninth Circuit concedes, this interpretation represents a statutory scheme that is vulnerable to circumvention of EMTALA's mandate. ${ }^{207}$ Therefore, the Sixth Circuit presents the optimal approach to EMTALA's stabilization requirement because it reflects the statute's purpose and is consistent with the Supreme Court's previous decisions.

204 Roberts v. Galen of Va., Inc., 525 U.S. 249, 250 (1999). An improper motive could be based on anything including indigency, race, or sex.

205 Id. at 252 (stating "[b]ut there is no question that the test of [EMTALA's stabilization requirement provision] does not require an "appropriate" stabilization, nor can it be reasonably read to require an improper motive.").

206 See Bryant v. Adventist Health Sys./West, Inc., 289 F.3d 1162, 1169

(9th Cir. 2002).

207 See id. 


\section{CONCLUSION}

The Sixth Circuit's interpretation of EMTALA's stabilization requirement represents the approach that most accurately construes the statute's meaning and the legislature's intent. First, the plain meaning of the statute defines stabilization in terms of medical treatment, and it also provides no limitation restricting EMTALA's coverage to patients in the emergency department. In fact, the statute contemplates "stabilization" as requiring additional treatment in the general hospital. Second, the legislative history indicates that Congress was concerned with the denial of treatment to patients coming to the emergency department. Mandating that EMTALA's protection follow patients who come to the emergency department throughout their stay at the hospital, even after admittance, guarantees patients will receive necessary treatment. Next, EMTALA does not supplant state medical malpractice laws. An EMTALA claim only becomes available to a potential plaintiff once the patient has been discharged or transferred, while medical malpractice claims may be made when medical professionals are negligent in providing treatment. Last, the Ninth Circuit's exception to its general holding would most likely be struck down by the Supreme Court, leaving the undesirable rule that anytime a patient was admitted, the stabilization requirement would be fulfilled, even when a hospital only admitted the patient to circumvent EMTALA. The Sixth Circuit's approach offers a rule that considers the possibility of improper motive while supporting the statute's overall goal of preventing patient dumping. 
